\title{
New Indole Alkaloids from Kopsia Singapurensis (RIDL.)
}

\author{
Kartini Ahmad ${ }^{1,2, *}$, Yusuke Hirasawa ${ }^{2}$, Alfarius Eko Nugroho ${ }^{2}$, A. Hamid A. Hadi ${ }^{3}$, Koichi Takeya ${ }^{4}$, \\ Noel F. Thomas ${ }^{3}$, Khalijah Awang ${ }^{3}$, Hiroshi Morita ${ }^{2}$, Tan Siow Ping ${ }^{1}$ and Mohd Azlan Nafiah ${ }^{1}$ \\ ${ }^{I}$ Department of Chemistry, Faculty of Science and Mathematics, Universiti Pendidikan Sultan Idris, 35900 Tanjung \\ Malim, Perak, Malaysia \\ ${ }^{2}$ Faculty of Pharmaceutical Sciences, Hoshi University, Ebara 2-4-41 Shinagawa-ku, Tokyo 142-8501, Japan \\ ${ }^{3}$ Department of Chemistry, Faculty of Science, University of Malaya, 50603 Kuala Lumpur, Malaysia \\ ${ }^{4}$ Tokyo University of Pharmaceutical and Life Science, 1432-1 Horinouchi, Tokyo 192-0392, Japan
}

\begin{abstract}
Study on chemical constituents from Kopsia singapurensis (Apocynaceae) yielded four new aspidofractinines: Singaporentine A (1), N(1)-formylkopsininic acid (2), $N(1)$-formylkopsininic acid- $N(4)$-oxide (3), 15-hydroxykopsamine (4); a new aspidospermatan: $14 \alpha$-hydroxy- $N(4)$-methylcondylocarpine (5) and a new akuamiline: singaporentinidine (6) together with 18 known indole alkaloids from different parts of the plant. The structures of these compounds were elucidated by combination of various spectroscopic methods.
\end{abstract}

Keywords: Indole, aspidofractinines, aspidospermatan, akuamiline, Apocynaceae.

\section{INTRODUCTION}

The genus Kopsia (Apocynaceae) comprises of 30 species which is native to China, India and Southeast Asia [1-7]. In Malay Peninsula, Kopsia singapurensis Ridl. is one of the 18 Kopsia species that are distributed from Negeri Sembilan southward to Singapore and common in lowland swampy forest $[8,9]$. This species is known to produce a large number of biologically active indole alkaloids possessing interesting skeletons [1-7]. Previous chemical investigation on Kopsia singapurensis afforded several skeletal types of indole alkaloids such as kopsingine, kopsaporine, kopsingarine [10], singapurensines A-D [11] and kopsiloscine A-F [12] (aspidofractinine type), rhazinilam and rhazinal [12] (aspidosperma type), vincophylline [12] (vincorine type), 16-epideacetyakuammiline [12] (akuammiline type), mersinaline and mersirachine [13] (mersinine type). Our continuing study on leaves, roots and barks of Kopsia singapurensis Ridl. have afforded four new aspidofractinines: Singaporentine A (1), $N(1)$-formylkopsininic acid (2), $N(1)$-formylkopsininic acid- $N(4)$-oxide (3), 15-hydroxykopsamine (4); a new aspidospermatan: $14 \alpha-$ hydroxy- $N(4)$-methylcondylocarpine (5) and a new akuamiline: singaporentinidine (6) together with 18 known indole alkaloids; from bark: venalstonine, venacarpine A, rhazinilam, pleicarpamine, 16-epideacetylakuammiline, 15hydroxykopsinine, 16-hydroxymethylpleiocarpamine, lonicerine, kopsinine- $N$-oxide and 16-epideacetylakuammiline$\mathrm{N}$-oxide; from leaves: kopsininic acid and kopsifoline A;

*Address correspondence to this author at the Department of Chemistry, Faculty of Science and Mathematics, Universiti Pendidikan Sultan Idris, 35900 Tanjung Malim, Perak, Malaysia; Tel: +6015-48117338;

Fax: +6015-48117296; E-mail: kartini@fsmt.upsi.edu.my from roots: kopsamine $N(4)$-oxide, 16-epiakuammiline, $\mathrm{N}$ methylpleiocarpamine, aspidodasycarpine, kopsamine, kopsinine and kopsininic acid. Their structures were elucidated by combination of various spectroscopic methods such as $1 \mathrm{D}$ and 2D NMR, IR, UV and MS. We will only describe the isolation and structural elucidation of these new compounds in the present paper.

\section{EXPERIMENTAL}

\section{General Experimental Procedures}

Spectra were recorded on the following instruments. Optical rotations at $25{ }^{\circ} \mathrm{C}$ were taken on Jasco DIP-1000 Digital polarimeter. UV spectra were recorded on a Shimadzu UVmini-1240 spectrophotometer and IR spectra on a Perkin Elmer 1600 spectrophotometer. UV, IR and optical rotation were recorded in methanol. CD spectra were recorded on a JASCO J-820 polarimeter. Mass spectra were obtained using LC-EIMS, Waters Micromass ZQ and a LTQ Orbitrap XL (Thermo Scientific) spectrometer. NMR spectra were recorded on a Bruker Avance 600 spectrometer and chemical shifts were reported using residual $\mathrm{CD}_{3} \mathrm{OD}\left(\delta_{\mathrm{H}}\right.$ 3.31 and $\left.\delta_{\mathrm{C}} 49.0\right)$ as internal standards. HPLC was performed on a C18 MG-II ( $\phi 10 \mathrm{~mm} 1 . \mathrm{D}$ x $250 \mathrm{~mm})$.

\section{Plant Material}

The barks and leave of Kopsia singapurensis were collected in Kluang, Johor, Malaysia in 2007. Identification was made by Mr. Teo Leong Eng, University of Malaya. Voucher specimens (KL 5334) were deposited at Herbarium of the Department of Chemistry, University of Malaya, Kuala Lumpur, Malaysia and at the Herbarium of the Forest Research Institute, Kepong, Malaysia. The roots of Kopsia singapurensis were collected in Kluang, Johor, Malaysia in 
2010. Identification was made by Mr. Teo Leong Eng, University of Malaya. Voucher specimens (KL 5724) were deposited at Herbarium of the Department of Chemistry, University of Malaya, Kuala Lumpur, Malaysia.

\section{Extraction and Isolation}

The dried bark $(3 \mathrm{~kg})$ of Kopsia singapurensis were first defatted in hexane by Soxhlet extractor for 17 hours. Then the extract was dried on the rotary evaporator. The plant material was dried and wetted with $10 \%$ ammonia solution and left for overnight. They were then re-extracted successively with $\mathrm{CH}_{2} \mathrm{Cl}_{2}$. After removal of the solvents, $50.0 \mathrm{~g} \mathrm{CH}_{2} \mathrm{Cl}_{2}$ crude extracts were obtained for the bark. The crude extract of the bark were then dissolved in hexane for three days to give crude which is dissolved in hexane $(9.0 \mathrm{~g})$. After evaporation of the solvent, $9.0 \mathrm{~g}$ of the crude was subjected to column chromatography over silica gel (gradient solvent system; $\mathrm{CHCl}_{3}$ and $\mathrm{MeOH}$ ) yielded 10 known compounds: venalstonine, venacarpine A, rhazinilam, pleicarpamine, 16-epideacetylakuammiline, 15-hydroxykopsinine, 16-hydroxymethylpleiocarpamine, lonicerine, kopsinine- $N$-oxide and 16 -epideacetylakuammiline- $N$-oxide.

The dried leaves (2 kg) of Kopsia singapurensis were ground and extracted exhaustively with hexane followed by $\mathrm{CH}_{2} \mathrm{Cl}_{2}$ by soxhlet extractor for 17 hours. After evaporation of the solvent, $20 \mathrm{~g}$ of $\mathrm{CH}_{2} \mathrm{Cl}_{2}$ crude extract was subjected to column chromatography over silica gel (gradient solvent system; $\mathrm{CHCl}_{3}$ and $\mathrm{MeOH}$ ) to give 28 fractions. Fractions 23-27, then were repeated $\mathrm{CC}$ and ODC silica gel $(20 \%$ $\mathrm{MeOH}, 80 \% \mathrm{H}_{2} \mathrm{O}, 0.1 \%$ acetic acid) afforded kopsininic acid (30.0 mg). Fractions 12-18 (10 g) was purified by CC (NH silica, ODS silica and normal silica gel) yielded a small amount of singaporentine $\mathrm{A}(\mathbf{1}, 2.6 \mathrm{mg})$. PTLC and $\mathrm{CH}_{2} \mathrm{Cl}_{2}$ crude extract $(40.0 \mathrm{mg})$ afforded kopsifoline A (11.6 mg).

The dried roots (1 kg) of Kopsia singapurensis were ground and extracted exhaustively with $\mathrm{MeOH}$ to give $35.0 \mathrm{~g}$ of $\mathrm{MeOH}$ crude extract. The $\mathrm{MeOH}$ crude extract $(20.0 \mathrm{~g})$ were further extracted with EtOAc / 3\% tartaric acid ( $\mathrm{pH} 2)$, $\mathrm{CHCl}_{3} /$ saturated $\mathrm{Na}_{2} \mathrm{CO}_{3}(\mathrm{pH} 10)$ to yielded EtOAc crude extract $\left(\begin{array}{ll}15.0 & \mathrm{~g}\end{array}\right)$ and alkaloid crude extract $(4.0 \mathrm{~g})$ respectively. The alkaloidal fraction $(2.59 \mathrm{~g})$ was subjected to a Sephadex LH-20 column with solvent system $\mathrm{CHCl}_{3} / \mathrm{MeOH}(1: 1)$ to give 20 fractions. Each series of fractions was then treated separately by extensive column chromatography. Fractions I and J (190.0 mg) was further purified by an ODS column $\left(\mathrm{MeOH} / \mathrm{H}_{2} \mathrm{O}+0.1 \%\right.$ formic acid, 2:8 \% 1:0) afforded $N(1)$-formylkopsininic acid (2, $18.8 \mathrm{mg})$ and $N(1)$-formylkopsininic acid- $N(4)$-oxide $(3,6.6$ $\mathrm{mg}$ ) together with kopsamine $N(4)$-oxide $(11.5 \mathrm{mg})$. Further purification on fractions eluted by the ODS column with an ODS HPLC $\left(\mathrm{MeCN} / \mathrm{H}_{2} \mathrm{O}+0.1 \%\right.$ formic acid, 2:8, flow rate $2 \mathrm{~mL} / \mathrm{min}$; UV detection at $220 \mathrm{~nm}$, Rt $15.0 \mathrm{~min}, 17.0 \mathrm{~min}$ and $21.0 \mathrm{~min}$ ) to give $14 \alpha$-hydroxy-N(4)-methylcondylocarpine $(\mathbf{5}, 5.3 \mathrm{mg})$ together with 16-epiakuammiline $(2.4$ $\mathrm{mg}), N$-methylpleiocarpamine $(7.6 \mathrm{mg})$ and aspidodasycarpine $(81.1 \mathrm{mg})$. The work-up procedure on fractions $\mathrm{M}$ and $\mathrm{N}(680.0 \mathrm{mg})$ with normal silica and followed by ODS column with an ODS HPLC $\left(\mathrm{MeCN} / \mathrm{H}_{2} \mathrm{O}+0.1 \%\right.$ formic acid, $2: 8$, flow rate $2 \mathrm{~mL} / \mathrm{min}$; UV detection at $220 \mathrm{~nm}$, Rt $18.0 \mathrm{~min}$ and $23.0 \mathrm{~min})$ to give 15 -hydroxykopsamine $(4,2.4$ $\mathrm{mg})$ and singaporentinidine $(6,3.5 \mathrm{mg})$ together with kopsamine (5.2 $\mathrm{mg})$, kopsinine (14.8 $\mathrm{mg}$ ) and kopsininic acid (2.0 mg).

Singaporentine A (1): light yellowish oil, with $|\alpha| \frac{28}{D}$ -23 (c 0.3, MeOH); UV (MeOH) $\lambda_{\max } 232,253$ and $310 \mathrm{~nm}$; IR (liquid film) $\lambda_{\max } 2970,1738$ and $1720(\mathrm{C}=\mathrm{O})$, and 1217 $\mathrm{cm}^{-1}$; HRESIMS $\mathrm{m} / \mathrm{z} 379.1659\left([\mathrm{M}+\mathrm{H}]^{+}\right.$; calcd. for $\left.\mathrm{C}_{22} \mathrm{H}_{23} \mathrm{~N}_{2} \mathrm{O}_{4}, 379.1658\right)$. ${ }^{1} \mathrm{H}$ and ${ }^{13} \mathrm{C}$ NMR see Table 1 and Table 2.

N(1)-Formylkopsininic acid (2): yellowish amorphous, with $|\alpha| \frac{28}{D}-304$ (c $\left.0.25, \mathrm{MeOH}\right) ; \mathrm{UV}(\mathrm{MeOH}) \lambda_{\max } 200$, 240, and $290 \mathrm{~nm}$; IR (liquid film) $\lambda_{\max } 3400(\mathrm{OH}), 1730$ and $1710(\mathrm{C}=\mathrm{O})$, and $1616 \mathrm{~cm}^{-1}$; HRESIMS $\mathrm{m} / \mathrm{z} 353.18391$ $\left([\mathrm{M}+\mathrm{H}]^{+}\right.$; calcd. for $\left.\mathrm{C}_{21} \mathrm{H}_{25} \mathrm{~N}_{2} \mathrm{O}_{3}, 353.18652\right) .{ }^{1} \mathrm{H}$ and ${ }^{13} \mathrm{C}$ NMR see Table 1 and Table 2.

$\boldsymbol{N}(1)-F o r m y l k o p s i n i n i c \quad$ acid- $\boldsymbol{N ( 4 ) - o x i d e ~ ( 3 ) : ~ l i g h t ~}$ yellowish amorphous, with $|\alpha| \frac{28}{D}-93$ (c $\left.0.25, \mathrm{MeOH}\right)$; UV $(\mathrm{MeOH}) \lambda_{\max } 200,240$ and $290 \mathrm{~nm}$; IR (liquid film) $\lambda_{\max }$ $3450(\mathrm{OH}), 1720(\mathrm{C}=\mathrm{O})$ and $1614 \mathrm{~cm}^{-1}$; HRESIMS $\mathrm{m} / z$ $369.17966\left([\mathrm{M}+\mathrm{H}]^{+}\right.$; calcd. for $\left.\mathrm{C}_{21} \mathrm{H}_{25} \mathrm{~N}_{2} \mathrm{O}_{4}, 369.18143\right) .{ }^{1} \mathrm{H}$ and ${ }^{13} \mathrm{C}$ NMR see Table $\mathbf{1}$ and Table 2.

15-Hydroxykopsamine (4): yellowish amorphous, with I los -19 (c 0.12, MeOH); UV (MeOH) $\lambda_{\max } 203,226$ and $290 \mathrm{~nm}$; IR (liquid film) $\lambda_{\max } 3450(\mathrm{OH})$ and $1710(\mathrm{C}=\mathrm{O})$ $\mathrm{cm}^{-1}$; HRESIMS $\mathrm{m} / \mathrm{z} 473.1934\left([\mathrm{M}+\mathrm{H}]^{+}\right.$; calcd. for $\left.\mathrm{C}_{24} \mathrm{H}_{29} \mathrm{~N}_{2} \mathrm{O}_{8}, 473.1924\right) .{ }^{1} \mathrm{H}$ and ${ }^{13} \mathrm{C}$ NMR see Table 1 and Table 2.

14 $\alpha$-Hydroxy-N(4)-methylcondylocarpine (5): light yellowish amorphous, with $|\alpha| \frac{28}{D}+386$ (c 0.25, MeOH); UV $(\mathrm{MeOH}) \lambda_{\max }$ 200, 224, 290 and $327 \mathrm{~nm}$; IR (liquid film) $\lambda_{\max } 3460(\mathrm{NH} / \mathrm{OH})$ and $1700(\mathrm{C}=\mathrm{O}) \mathrm{cm}^{-1}$; HRESIMS $\mathrm{m} / z$ $353.18396\left([\mathrm{M}+\mathrm{H}]^{+}\right.$; calcd. for $\left.\mathrm{C}_{21} \mathrm{H}_{25} \mathrm{~N}_{2} \mathrm{O}_{3}, 353.18652\right) .{ }^{1} \mathrm{H}$ and ${ }^{13} \mathrm{C}$ NMR see Table $\mathbf{1}$ and Table 2.

Singaporentinidine (6): light yellowish amorphous, with $|\alpha| \frac{28}{D}-2$ (c 0. $\left.175 \mathrm{MeOH}\right) ; \mathrm{UV}(\mathrm{MeOH}) \lambda_{\max } 200,220,280$ and $327 \mathrm{~nm}$; IR (liquid film) $\lambda_{\max } 3440(\mathrm{NH} / \mathrm{OH})$ and 1730 $(\mathrm{C}=\mathrm{O}) \mathrm{cm}^{-1}$; HRESIMS $\mathrm{m} / z \quad 309.1577$ ([M] $]^{+}$; calcd. for $\left.\mathrm{C}_{19} \mathrm{H}_{21} \mathrm{~N}_{2} \mathrm{O}_{2}, 309.1598\right) .{ }^{1} \mathrm{H}$ and ${ }^{13} \mathrm{C}$ NMR see Table $\mathbf{1}$ and Table 2.

\section{RESULTS AND DISCUSSION}

Singaporentine A (1) was isolated from dichloromethane extract of the leaves of $K$. singapurensis as a light yellowish oil, with $|\alpha| \frac{28}{D}-23^{\circ}(c=0.3, \mathrm{MeOH})$. The UV spectrum showed the maximum absorptions at 232, 253 and $310 \mathrm{~nm}$ indicating the presence of an indolenine chromophore $[13,14]$. The IR spectrum showed the absorption bands at 1738 and $1720 \mathrm{~cm}^{-1}$ which were assigned to the present of a carbonyl groups for methyl ester and lactam [15], respectively. 
Table 1. ${ }^{1} \mathrm{H}$ NMR $\left[600 \mathrm{MHz}, \delta_{\mathrm{H}}(J \mathrm{~Hz})\right]$ of 1 - 6 in $\mathrm{CDCl}_{3}$

\begin{tabular}{|c|c|c|c|c|c|c|}
\hline \multirow{2}{*}{ Position } & \multicolumn{6}{|c|}{$\delta \mathbf{H}, J \mathbf{H z}$} \\
\hline & 1 & 2 & 3 & 4 & 5 & 6 \\
\hline $\mathrm{NH}$ & & & & & $8.52(\mathrm{br}, \mathrm{s})$ & \\
\hline \multicolumn{7}{|l|}{2} \\
\hline \multirow{2}{*}{3} & $3.62(d, 18.0)$ & $3.20(\mathrm{~m})$ & $3.93(\mathrm{~d}, 11.0)$ & $3.01(\mathrm{~m})$ & $3.47(\mathrm{~m})$ & 4.97 (br, s) \\
\hline & $4.60(d, 18.0)$ & $3.27(\mathrm{~m})$ & $4.17(\mathrm{~d}, 11.0)$ & $3.10(\mathrm{~m})$ & $3.85(\mathrm{~m})$ & \\
\hline \multirow{2}{*}{5} & & $3.39(\mathrm{t}, 10.0)$ & $3.80(\mathrm{~d}, 10.0)$ & $3.00(\mathrm{~m})$ & $3.70(\mathrm{~m})$ & $3.59(\mathrm{~m})$ \\
\hline & & $3.52(\mathrm{t}, 10.0)$ & $3.96(\mathrm{~d}, 10.0)$ & $3.05(\mathrm{~m})$ & $3.74(\mathrm{~m})$ & $4.86(\mathrm{~m})$ \\
\hline \multirow{2}{*}{6} & $2.56(d, 18.0)$ & $1.74(\mathrm{~m})$ & $1.99(\mathrm{~m})$ & $1.66(\mathrm{~m})$ & $2.23(\mathrm{~m})$ & $3.09(\mathrm{~m})$ \\
\hline & $3.26(d, 18.0)$ & $2.80(\mathrm{~m})$ & $2.98(\mathrm{~m})$ & $2.12(\mathrm{~m})$ & $3.13(\mathrm{~m})$ & \\
\hline \multicolumn{7}{|l|}{7} \\
\hline \multicolumn{7}{|l|}{8} \\
\hline 9 & $6.93(d, 8.0)$ & $7.50(\mathrm{~d}, 8.0)$ & $7.68(\mathrm{~d}, 8.0)$ & $6.77(\mathrm{~d}, 8.0)$ & $7.59(\mathrm{~d}, 7.0)$ & $7.46(\mathrm{~d}, 8.0)$ \\
\hline 10 & $7.22(t, 8.0)$ & $6.71(\mathrm{t}, 8.0)$ & $6.77(\mathrm{t}, 8.0)$ & $6.52(\mathrm{~d}, 8.0)$ & $6.97(\mathrm{t}, 7.0)$ & $7.08(\mathrm{t}, 8.0)$ \\
\hline 11 & $6.9(\mathrm{~d}, 8.0)$ & $6.96(\mathrm{t}, 8.0)$ & $7.00(\mathrm{t}, 8.0)$ & & $7.21(\mathrm{t}, 7.0)$ & $7.17(\mathrm{t}, 8.0)$ \\
\hline 12 & & $6.68(\mathrm{~d}, 8.0)$ & $6.66(\mathrm{~d}, 8.0)$ & & $6.98(\mathrm{~d}, 7.0)$ & $7.34(\mathrm{~d}, 8.0)$ \\
\hline \multicolumn{7}{|l|}{13} \\
\hline \multirow{2}{*}{14} & $5.74(\mathrm{~d}, 10.0)$ & $1.64(\mathrm{~m})$ & $1.88(\mathrm{~m})$ & $1.53(\mathrm{~m})$ & $4.18(\mathrm{br}, \mathrm{s})$ & $2.34(\mathrm{~d}, 7.0)$ \\
\hline & & $1.89(\mathrm{~m})$ & $1.93(\mathrm{~m})$ & $1.79(\mathrm{~m})$ & & \\
\hline \multirow[t]{2}{*}{15} & $5.63(\mathrm{~d}, 10.0)$ & $1.37(\mathrm{~m})$ & $1.42(\mathrm{~m})$ & $\begin{array}{c}3.45 \\
(\mathrm{dd}, 4.0,12.0)\end{array}$ & $3.61(\mathrm{br}, \mathrm{s})$ & $3.80(\mathrm{~s})$ \\
\hline & & $1.62(\mathrm{~m})$ & $1.85(\mathrm{~m})$ & & & \\
\hline 16 & & $2.85(\mathrm{~m})$ & $2.93(\mathrm{~m})$ & & & $4.08(\mathrm{~s})$ \\
\hline \multirow[b]{2}{*}{17} & $1.81(\mathrm{~d}, 12.4)$ & $1.60(\mathrm{~m})$ & $1.53(\mathrm{~m})$ & $1.89(\mathrm{~d}, 15.0)$ & & \\
\hline & $2.24(\mathrm{~d}, 13.2)$ & $2.56(\mathrm{~m})$ & $2.63(\mathrm{~m})$ & $\begin{array}{c}2.58 \\
(\mathrm{dd}, 2,15.0)\end{array}$ & & \\
\hline \multirow{2}{*}{18} & $2.37(\mathrm{~m})$ & $1.39(\mathrm{~m})$ & $1.36(\mathrm{~m})$ & $1.51(\mathrm{~m})$ & $1.75(\mathrm{~d}, 7.0)$ & $1.73(\mathrm{~d}, 7.0)$ \\
\hline & $2.42(\mathrm{~m})$ & $1.84(\mathrm{~m})$ & $1.65(\mathrm{~m})$ & $2.38(\mathrm{t}, 11.0)$ & & \\
\hline \multirow{2}{*}{19} & $1.21(\mathrm{~m})$ & $1.35(\mathrm{~m})$ & $1.51(\mathrm{~m})$ & $1.12(\mathrm{t}, 11.0)$ & $5.95(\mathrm{q}, 7.0)$ & $5.49(\mathrm{q}, 7.0)$ \\
\hline & $1.74(\mathrm{~m})$ & $1.57(\mathrm{~m})$ & $1.59(\mathrm{~m})$ & $2.17(\mathrm{~m})$ & & \\
\hline \multicolumn{7}{|l|}{20} \\
\hline \multirow{2}{*}{21} & 3.49 & $3.60(\mathrm{~s})$ & $4.01(\mathrm{~s})$ & $2.89(\mathrm{~s})$ & $5.37(\mathrm{br}, \mathrm{s})$ & $3.97(\mathrm{~d}, 14.0)$ \\
\hline & & & & & & $4.88(\mathrm{~m})$ \\
\hline 22 & $3.73(\mathrm{~s})$ & & & & $3.81(\mathrm{~s})$ & \\
\hline 23 & & $8.40(\mathrm{~s})$ & $8.43(\mathrm{~s})$ & $3.76(\mathrm{~s})$ & $3.51(\mathrm{~s})$ & \\
\hline 24 & $3.97(\mathrm{~s})$ & & & & & \\
\hline 25 & & & & $3.89(\mathrm{~s})$ & & \\
\hline 26 & & & & $5.90(\mathrm{~s})$ & & \\
\hline 16-OH & & & & $6.92(\mathrm{br}, \mathrm{s})$ & & \\
\hline
\end{tabular}


Table 2. ${ }^{13} \mathrm{C}$ NMR [150 MHz, $\delta_{\mathrm{C}}$ ] of 1 - 6 in $\mathrm{CDCl}_{3}$

\begin{tabular}{|c|c|c|c|c|c|c|}
\hline Position & \multicolumn{6}{|c|}{$\delta \mathrm{C}$} \\
\hline 2 & 183.3 & 65.2 & 65.1 & 74.8 & 167.8 & 129.8 \\
\hline 3 & 40.0 & 46.6 & 63.2 & 45.9 & 61.5 & 70.1 \\
\hline 6 & 39.1 & 33.6 & 32.4 & 37.3 & 41.5 & 18.5 \\
\hline 7 & 55.3 & 58.2 & 58.8 & 57.6 & 58.3 & 104.9 \\
\hline 8 & 146.7 & 137.4 & 137.4 & 123.3 & 133.3 & 125.9 \\
\hline 9 & 112.8 & 122.7 & 124.3 & 114.5 & 121.0 & 118.8 \\
\hline 12 & 151.4 & 113.1 & 112.7 & 134.2 & 112.0 & 112.1 \\
\hline 13 & 142.3 & 147.1 & 148.3 & 135.7 & 145.9 & 138.0 \\
\hline 14 & 123.9 & 15.1 & 19.3 & 26.4 & 67.1 & 34.8 \\
\hline 15 & 132.4 & 33.3 & 31.9 & 76.2 & 44.4 & 42.6 \\
\hline 16 & 56.6 & 42.1 & 42.8 & 74.6 & 101.0 & 72.3 \\
\hline 17 & 41.7 & 32.8 & 31.8 & 34.5 & 168.0 & 168.0 \\
\hline 18 & 39.6 & 31.6 & 34.3 & 23.5 & 13.3 & 14.4 \\
\hline 24 & 55.5 & & & 156.1 & & \\
\hline 25 & & & & 53.3 & & \\
\hline 26 & & & & 100.3 & & \\
\hline $16-\mathrm{OH}$ & & & & & & \\
\hline
\end{tabular}

The HRESIMS of 1 gives a pseudomolecular ion peak at $\mathrm{m} / \mathrm{z}$ 379 corresponding to the molecular formula of $\mathrm{C}_{22} \mathrm{H}_{22} \mathrm{~N}_{2} \mathrm{O}_{4}$ $\left(\mathrm{m} / \mathrm{z} 379.1659[\mathrm{M}+\mathrm{H}]^{+}\right.$; calc. 379.1658$) .{ }^{1} \mathrm{H}$ and ${ }^{13} \mathrm{C} \mathrm{NMR}$ data (Table 1 and Table 2 ) indicated the presence of five $\mathrm{sp}^{2}$ methines, six $\mathrm{sp}^{2}$ quaternary carbons, five $\mathrm{sp}^{3}$ methylenes, one $\mathrm{sp}^{3}$ methine, three $\mathrm{sp}^{3}$ quaternary carbons and two methyl groups. Two of the $\mathrm{sp}^{2}$ quaternary carbons $\left(\delta_{\mathrm{C}} 183.3\right.$, 142.3) were attached to the nitrogen atom in the indolenine ring $(\mathrm{N}-1)$. One $\mathrm{sp}^{3}$ methylene $\left(\delta_{\mathrm{C}} 40.0\right)$, one $\mathrm{sp}^{3}$ methine $\left(\delta_{\mathrm{C}}\right.$ $64.8)$ and one $\mathrm{sp}^{2}$ quaternary carbon $\left(\delta_{\mathrm{C}} 171.1\right)$ were attached to the other nitrogen atom $(\mathrm{N}-4)$. The ${ }^{1} \mathrm{H}-{ }^{1} \mathrm{H}$ COSY spectrum of 1 suggested the following three fragments; C-3-C-15, C9-C-11 and C-18-C-19. The HMBC spectrum showed correlation between $\mathrm{C}-18$ and the isolated methylene protons of $\mathrm{C}-17$ which resonated as a broad doublet $(J=13.2 \mathrm{~Hz})$ in the ${ }^{1} \mathrm{H}$ NMR spectrum. In addition, correlation signals were also observed for $\mathrm{H}_{2}-17$ and $\mathrm{C}-2, \mathrm{C}-16, \mathrm{C}-18, \mathrm{C}-19$ and C-20 thus confirmed the five- membered ring nature of ring $\mathrm{F}$ and its connection to both ring $\mathrm{C}$ and $\mathrm{D}$, respectively. The methoxy at C-12 was confirmed by the presence of crosspeaks between $\mathrm{H}_{3}-24$ and $\mathrm{C}-12$, and $\mathrm{H}-9$ with $\mathrm{C}-7$. The HMBC cross-peaks of $\mathrm{H}-3 \beta$ to $\mathrm{C}-5$ and $\mathrm{C}-21$ indicated the connection among C-3, C-5 and C-21 through N-4. The carbonyl signal at $\delta_{\mathrm{C}} 171.1$ and the IR absorption of carbonyl group at $1720 \mathrm{~cm}^{-1}$ indicated the presence of the fivemembered lactam ring (ring E) [15]. The connection among C-15, C-17, C-19 and C-21 through C-20 was deduced from HMBC correlations of $\mathrm{H}-14$ to $\mathrm{C}-20$, and $\mathrm{H}-15$ to $\mathrm{C}-17, \mathrm{C}-$ 19 and $\mathrm{C}-21$. In addition, the connections between $\mathrm{C}-2, \mathrm{C}$ $17, \mathrm{C}-18$ and C-22 through C-16 were elucidated by HMBC 


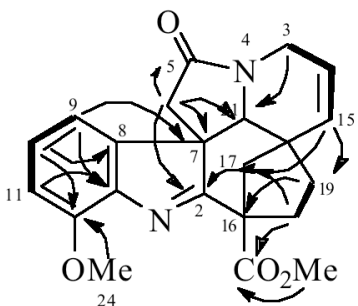

1

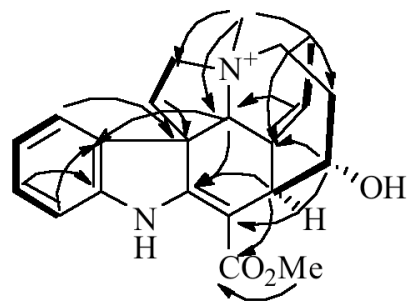

5

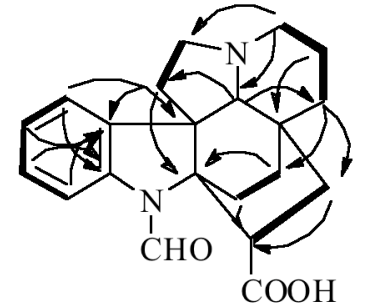

2

3: $\mathrm{N4} \rightarrow \mathrm{O}$

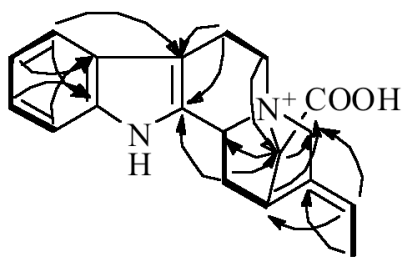

6

Fig. (1). Selected 2D NMR correlation for 1, 2, 4, 5 and 6.

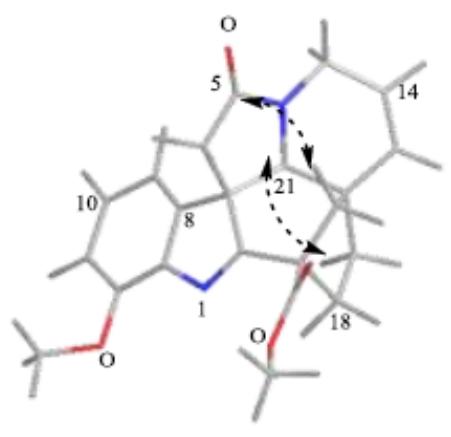

1

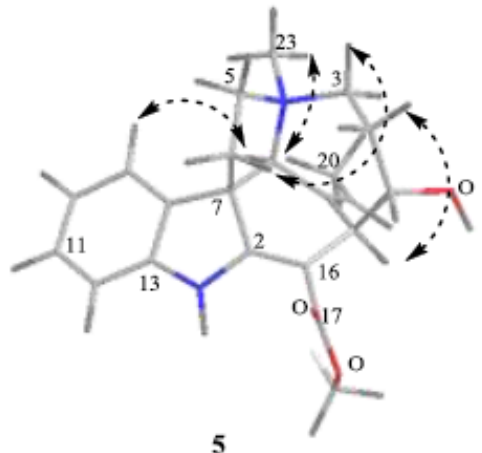

Fig. (2). Selected NOSEY correlations for 1, 2, 4, 5 and 6.

correlations of $\mathrm{H}-19 \beta$ to $\mathrm{C}-16, \mathrm{H}-18 \beta$ to $\mathrm{C}-17$ and $\mathrm{C}-22$, and $\mathrm{H}-17 \alpha$ to $\mathrm{C}-2$. These observations further confirmed that the six-membered ring $\mathrm{C}$ is fused to the five-membered ring $\mathrm{F}$. The connectivity between the methoxy group $\left(\mathrm{OCH}_{3}-23\right)$ and C-22 was established from HMBC correlations between of $\mathrm{H}_{3}-23$ and $\mathrm{C}-22$. Thus, the gross structure of singaporentine A was deduced to be $\mathbf{1}$ (Fig. 1). The relative stereochemistry of 1 was established by NOESY correlations as shown in the computer-generated 3D drawing (Fig. 2). NOESY

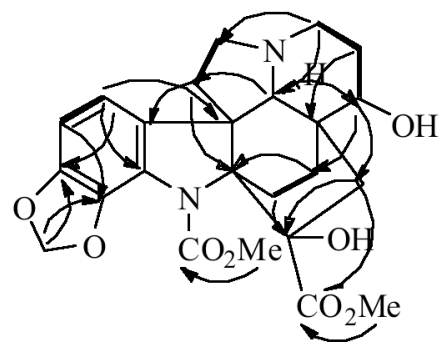

4

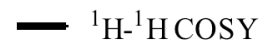

$7 \mathrm{HMBC}$

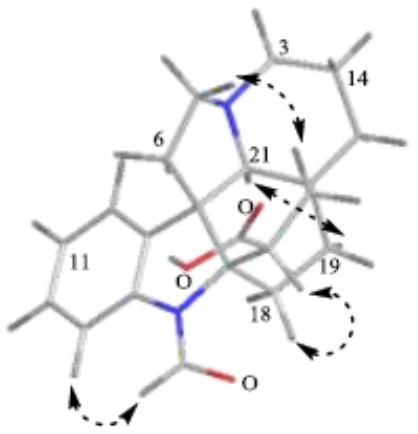

2

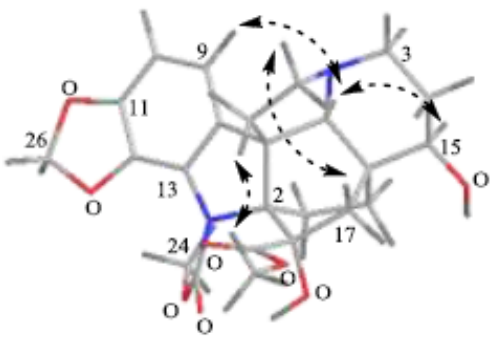

4

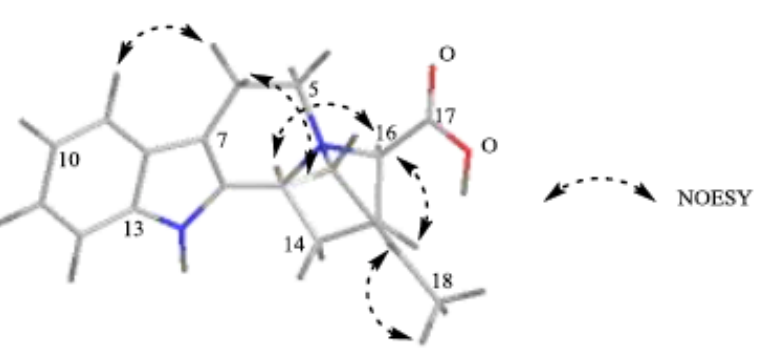

6

correlations of $\mathrm{H}-6 / \mathrm{H}-17 \beta$ and $\mathrm{H}-19 \alpha / \mathrm{H}-21$ indicated that singaporentine A possessed the same stereochemistry with kopsifoline E [16], previously isolated from the leaf of $K$. fruticosa. Therefore the relative stereochemistry of $\mathbf{1}$ is as depicted in Fig. (2).

$\mathrm{N}(1)$-Formylkopsininic acid (2) was isolated from the alkaloid crude extract of the roots of $\mathrm{K}$. singapurensis as yellowish amorphous with $|\alpha| \frac{28}{D}-304$ (c $\left.0.25, \mathrm{MeOH}\right)$. It 
was revealed to have the molecular formula $\mathrm{C}_{21} \mathrm{H}_{24} \mathrm{~N}_{2} \mathrm{O}_{3}$, by HRESITOFMS $\left[\mathrm{m} / \mathrm{z} 353.18391(\mathrm{M}+\mathrm{H})^{+}, \Delta-2.61 \mathrm{mmu}\right]$. The UV spectrum showed absorptions at 240 and $290 \mathrm{~nm}$ which showed characteristic of an indoline chromophore $[17,18]$. The IR spectrum indicated absorptions for a hydroxyl group $\left(3400 \mathrm{~cm}^{-1}\right)$, two carbonyl groups (1730 $\mathrm{cm}^{-1}$ and $\left.1710 \mathrm{~cm}^{-1}\right)$ and aromatic ring $\left(1616 \mathrm{~cm}^{-1}\right)$. The ${ }^{1} \mathrm{H}$ and ${ }^{13} \mathrm{C}$ NMR spectra (Table $1 \&$ Table 2 ) of 2 resembled those of kopsininic acid, which was also isolated from the leaves extract of the same plant [17], with an additional signal indicative of a formamide group $\left(\delta_{\mathrm{H}} 8.40\right.$ and $\delta_{\mathrm{C}}$ 167.6). The structure of $\mathbf{1}$ as the N(1)-formyl derivative of kopsininic acid was confirmed by analysis of the 2D NMR data (Fig. 1) as follows. The ${ }^{1} \mathrm{H}-{ }^{1} \mathrm{H}$ COSY correlations revealed the presence of $-\mathrm{CHCHCHCH}-(\mathrm{C}-9 \sim \mathrm{C}-12)$, $\mathrm{CH}_{2} \mathrm{CH}_{2}-(\mathrm{C}-5, \mathrm{C}-6),-\mathrm{CH}_{2} \mathrm{CH}_{2} \mathrm{CH}_{2}-(\mathrm{C}-3, \mathrm{C}-14, \mathrm{C}-15)$, $\mathrm{CH}_{2} \mathrm{CH}_{2^{-}}$(C-18, C-19), and - $\mathrm{CHCH}_{2-}$ (C-16, C-17) fragments. HMBC correlations of $\mathrm{H}-6$ to $\mathrm{C}-2$ and $\mathrm{C}-8, \mathrm{H}-9$ to $\mathrm{C}-7$ and $\mathrm{C}-13, \mathrm{H}-12$ and $\mathrm{H}-10$ to $\mathrm{C}-8$ confirmed the presence of the indoline ring. The connectivity of C-3, C-5 and $\mathrm{C}-21$ through a nitrogen atom was deduced from the HMBC cross-peaks of H2-3 to C-5 and C-21. The HMBC correlations of $\mathrm{H} 2-18$ to $\mathrm{C}-16, \mathrm{H} 2-19$ to $\mathrm{C}-2$ and $\mathrm{H}-21$ to C-6 suggested the connectivity of $\mathrm{C}-16$ and $\mathrm{C}-18$ to $\mathrm{C}-2$ and $\mathrm{C}$ 21 to C-7. The HMBC correlations from $\mathrm{H} 2-14$ to C-20, H15 to $\mathrm{C}-17$ and $\mathrm{C}-19$, and $\mathrm{H}-21$ to $\mathrm{C}-15$ indicated the connectivity of C-15, C-17, C-19 and C-21 through C-20. Finally, the presence of a formamide $\left(\delta_{\mathrm{H}} 8.40 ; \delta_{\mathrm{C}} 167.6\right)$ attached to the nitrogen atom $(\mathrm{N}-1)$ was indicated by a NOESY correlation of $\mathrm{H}-12 / \mathrm{CHO}$ (Fig. 2), and the presence of a hydroxylcarbonyl connected to $\mathrm{C}-16$ was deduced from the HMBC correlations of $\mathrm{H} 2-17$ to $\mathrm{C}-22$. The relative configuration of 2 was deduced by NOESY correlations as shown in the computer-generated 3D drawing (Fig. 2). The NOESY correlations of $\mathrm{H}-5 \mathrm{a} / \mathrm{H}-17 \mathrm{~b}$ and $\mathrm{H}-19 \mathrm{a} / \mathrm{H}-21$ established the relative configuration of C-2, C-7, C-20 and $\mathrm{C}-21$. The orientation of $\mathrm{H}-16$ was deduced to be $\alpha$ from the NOESY correlations of $\mathrm{H}-16 / \mathrm{H}-18 \mathrm{~b}$. Therefore, the relative configuration of $\mathbf{2}$ was assigned to be a depicted in Fig. (2).

$N(1)$-Formylkopsininic acid- $N(4)$-oxide (3) was isolated as yellowish amorphous, with $\left.|\alpha| \frac{28}{D}-93(c 0.25, \mathrm{MeOH})\right\}$, form the alkaloid crude extract of $K$. singapurensis. It showed a pseudo-molecular ion peak at $\mathrm{m} / \mathrm{z} 369.17966$ $\left([\mathrm{M}+\mathrm{H}]^{+}, \Delta-1.77 \mathrm{mmu}\right)$, which is consistent to the molecular formula $\mathrm{C}_{21} \mathrm{H}_{24} \mathrm{~N}_{2} \mathrm{O}_{4}$, differing from 2 by addition of one oxygen atom. The similar IR and UV spectra to 2 were observed for 3. Comparison of the ${ }^{1} \mathrm{H}$ and ${ }^{13} \mathrm{C}$ NMR data of $\mathbf{3}$ with $\mathbf{2}$ (Table $\mathbf{1} \&$ Table 2 ) suggested that $\mathbf{3}$ is closely related to $\mathbf{2}$ except for the characteristic downfield chemical shifts involving protons and carbons at position 3 $\left(\delta_{\mathrm{H}} 3.93\right.$ and $\left.4.17, \delta_{\mathrm{C}} 63.2\right), 5\left(\delta_{\mathrm{H}} 3.80\right.$ and $\left.3.96, \delta_{\mathrm{C}} 63.8\right)$ and $21\left(\delta_{\mathrm{H}} 4.01, \delta_{\mathrm{C}} 83.1\right)$, indicating the presence of $N(4)$-oxide.

15-Hydroxykopsamine (4) was isolated as yellowish amorphous with $|\alpha| \frac{28}{D}-19$ (c $\left.\left.0.12, \mathrm{MeOH}\right)\right\}$ showed a molecular formula $\mathrm{C}_{24} \mathrm{H}_{28} \mathrm{~N}_{2} \mathrm{O}_{8}$, which was determined by
HRESITOFMS $\left[\mathrm{m} / \mathrm{z} 473.1934(\mathrm{M}+\mathrm{H})^{+}, \Delta+1.0 \mathrm{mmu}\right]$. The IR absorption band at $3450 \mathrm{~cm}^{-1}$ was characteristic of amino or hydroxy group and the band at $1710 \mathrm{~cm}^{-1}$ indicated the presence of a carbonyl group. The UV spectrum showed the maximum absorption at 203, 226 and $290 \mathrm{~nm}$ which were characteristic of a indoline chromophore [17, 18]. The NMR data for 4 resembled those of kopsamine which was isolated from the leaves extract of $K$. pauciflora Hook $\mathrm{f}$ [16]. The significant difference between both was the presence of an oxymethine signal $\left(\delta_{\mathrm{H}} 3.80, \mathrm{~s} ; \delta_{\mathrm{C}} 76.2\right)$ in place of the $\mathrm{CH}_{2}-$ 15 signal of kopsamine. Thus, 4 was assumed to be a 15 hydroxy derivative of kopsamine, and this assumption was further confirmed by the HMBC correlations of $\mathrm{H}-15$ with C-3 and C-21 (Fig. 1). The relative configuration of 4 was established by NOESY correlations (Fig. 2) to be similar to kopsamine, with the NOESY correlation of $\mathrm{H}-15 / \mathrm{H}-21$ indicated that $\mathrm{H}-15$ took an $\alpha$-orientation. Finally, $\mathrm{C}-15$ was determined to have the $R$-configuration by employing the advanced Mosher's method.

$14 \alpha$-Hydroxy-N(4)-methylcondylocarpine (5) was isolated as light yellowish amorphous with $|\alpha| \frac{28}{D}+386$ (c $0.25, \mathrm{MeOH})\}$ which showed molecular ion peak at $\mathrm{m} / \mathrm{z}$ $353.18396([\mathrm{M}]+, \Delta-2.56 \mathrm{mmu})$. It was consistent to the molecular formula $\mathrm{C}_{21} \mathrm{H}_{25} \mathrm{~N}_{2} \mathrm{O}_{3}$. Its $\mathrm{UV}$ absorption maxima at 224, 290, and $327 \mathrm{~nm}$ suggested the presence of an anilinoacrylate chromophore $[5,19]$. The IR spectrum showed absorption band at $3460 \mathrm{~cm}^{-1}$ and $1700 \mathrm{~cm}^{-1}$ indicating the presence of an amine and/or a hydroxyl and an ester carbonyl groups, respectively. The ${ }^{1} \mathrm{H}$ and ${ }^{13} \mathrm{C}$ NMR data (Table 1 and Table 2) were reminiscent of those of $14 \alpha$ hydroxycondylocarpine [20] except for the additional methyl signal $\left(\delta_{\mathrm{H}} 3.81, \delta_{\mathrm{C}} 51.7\right)$ and the downfield chemical shifts of protons and carbons at position $3\left(\delta_{\mathrm{H}} 3.47\right.$ and $\left.3.85, \delta_{\mathrm{C}} 61.5\right)$, $5\left(\delta_{\mathrm{H}} 3.70\right.$ and $\left.3.74, \delta_{\mathrm{C}} 64.5\right)$ and $21\left(\delta_{\mathrm{H}} 5.37, \delta_{\mathrm{C}} 72.1\right)$, suggesting the presence of an N(4)-methyl. The position of the additional methyl was verified by HMBC correlations from $\mathrm{H} 3-23$ to C-3, C-5, and C-21 (Fig. 1) and the relative configuration of 4 was deduced by NOESY correlations to be the same as $14 \alpha$-hydroxycondylocarpine (Fig. 2). Thus, compound 5 was concluded to be $14 \alpha$-hydroxy-N(4)methylcondylocarpine.

Singaporentinidine (6) with $\left.|\alpha| \frac{28}{D}-2(c 0.175, \mathrm{MeOH})\right\}$ was isolated as light yellowish amorphous. It showed a molecular formula $\mathrm{C}_{19} \mathrm{H}_{21} \mathrm{~N}_{2} \mathrm{O}_{2}$, which was determined by HRESITOFMS [m/z $309.1577(\mathrm{M})+, \Delta-2.1 \mathrm{mmu}$ ]. The IR absorption at $3440 \mathrm{~cm}^{-1}$ was indicating the presence of amino or hydroxyl group and the band at $1730 \mathrm{~cm}^{-1}$ indicated the presence of a carbonyl group. The UV spectrum revealed the maximum absorption at 200, 220, 280 and $327 \mathrm{~nm}$ which were characteristic of an indole chromophore [17, 18]. Analysis of the 1D and 2D NMR data of 6 (Fig. 1) revealed a planar structure which is related to excelsinidine [21] isolated from Aspidosperma excelsum, and the difference was the presence of a proton at $\mathrm{C}-16$ in 5 


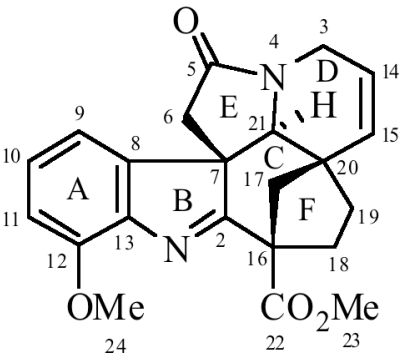

1

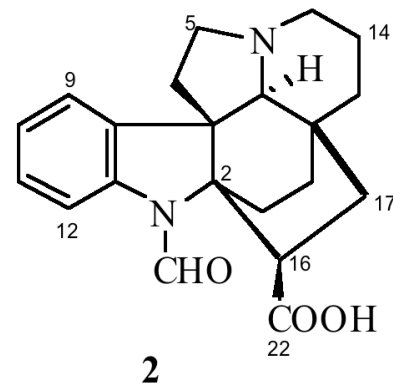

3: $\mathrm{N} 4 \rightarrow \mathrm{O}$

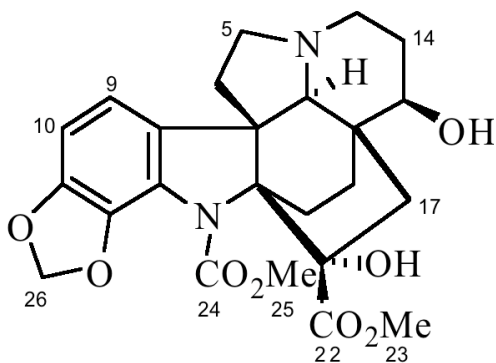

4

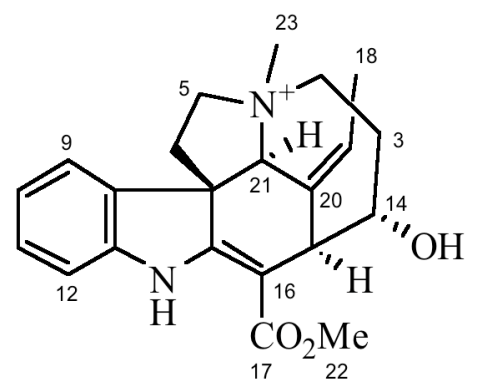

5

instead of a hydroxymethyl in excelsinidine. Analysis of the NOESY data (Fig. 2) established the relative configuration of 6 . The E configuration of $\mathrm{C}-19$ double bond was deduced from the NOESY correlations of H-15/H3-18 and H-19/H21a. The $\alpha$-orientation of C-3 was suggested by NOESY cross-peaks between $\mathrm{H}-3 / \mathrm{H}-21 \mathrm{~b}$ and the orientation of $\mathrm{H}-16$ was deduced from the NOESY correlation of $\mathrm{H}-6 / \mathrm{H}-16$. Thus, the relative configuration of 5 was assigned to be as depicted in Fig. (2).

Biogenetically, the skeleton of 1-6 can be derived from the corynantheine skeleton. C-16 N-4 cyclization of a corynantheine skeleton would yield an akuammiline skeleton as in 6. Rearrangements of a corynantheine skeleton may yield a stemmadenine skeleton, of which the aspidofractinine (1-4) and aspidospermatan (5) skeleton can be derived.

\section{CONFLICT OF INTEREST}

The authors confirm that this article content has no conflict of interest.

\section{ACKNOWLEDGEMENTS}

We gratefully acknowledge the financial support provided in part by a Grant-in-aid for Scientific Research from the Ministry of Education, Culture, Sports, Science, and Technology of Japan and a grant from The Open Research Center Project of Hoshi University, Japan, Ministry of Higher Education, Malaysia and University Pendidikan Sultan Idris. This work was also partly supported by a Grant (HIR UM-MOHE F000009-21001) in University of Malaya.

\section{REFERENCES}

[1] Homberger, K.; Hesse, M. Kopsirachin, ein ungewöhnliches alkaloid aus der Apocynaceae Kopsia dasyrachis Ridl. Helv. Chim. Acta, 1984, 67, 237-248.
[2] Homberger, K.; Hesse, M. Indole alkaloids of Kopsia dasyrachis RIDL. 185. naturally-occurring organic-substances, Helv. Chim. Acta, 1982, 65 (8), 2548-2557.

[3] Subramaniam, G.; Choo, Y. M.; Hiraku, O.; Komiyama, K.; Kam. T.S. The alkaloids of the mersinine group: a new subclass of the monoterpenoid indole alkaloids from Kopsia. Tetrahedron, 2008 , 64, 1397-1408

[4] Lim, K. H.; Kam, T. S. Methyl chanofruticosinate alkaloids from Kopsia arborea. Phytochemistry, 2008, 69, 558-561.

[5] Lim, K. H.; Hiraku, O.; Komiyama, K.; Koyano, T.; Hayashi, M. Kam, T. S. Biologically active indole alkaloids from Kopsia arborea. J. Nat. Prod., 2007, 70, 1302-1307.

[6] Lim, K. H.; Kam, T. S. Seco-leuconoxine and oxo-pericine derivatives from Kopsia. Helv. Chim. Acta, 2007, 90, 31-35.

[7] Awang, K.; Sevenet, T.; Pais, M.; Hadi, A.H.A. Alkaloids of Kopsia lapidilecta. J. Nat. Prod., 1993, 56(7), 1134-1139.

[8] Corner, E. J. H. Wayside Trees of Malaya, $2^{\text {nd }}$ ed.; vol.1, VCG Gatrell, Government Printer: Singapore, 1952.

[9] Burkill, I.; H. A Dictionary of the Economic Products of the Malay Peninsula, Ministry of Agriculture and Cooperatives: Kuala Lumpur, Malaysia, 1966

[10] Thomas, D. W; Biemann, K; Kiang, A. K.; Amarasingham, A. K. Structures of the indole alkaloids kospingine and kipsaporine $J$ Am. Chem. Soc., 1967, 89, 3235-3242.

[11] Awang, K. Thoison, O. Hadi, A. H. A. Pais, M. Sevenet, T. Alkaloids from Kopsia singapurensis. Nat. Prod. Lett., 1993, 3(4), 283-289.

[12] Subramaniam, G.; Hiraku, O. Hayashi, M. Koyano, T. Komiyama, K. Kam, T. S. Biologically active aspidofractinine, rhazinilam, akuammiline, and vincorine alkaloids from Kopsia. J. Nat. Prod., 2007, 70, 1783-1789.

[13] Subramaniam, G. Kam, T. S. Mersinaline and mersirachine, novel quinolinic alkaloids of the mersinine group from Kopsia. Tetrahedron Lett., 2007, 48, 6677-6680.

[14] Kam, T. S.; Choo, Y. M. Kopsifolines A, B, and C, novel indole alkaloids with a hexacyclic carbon skeleton from Kopsia. Tetrahedron Lett., 2003, 44, 1317-1319.

[15] Pavia, D. L. Lampman, G. M. Kriz, G. S. Introduction to Spectroscopy, $3^{\text {rd }}$ ed., Brooks/Cole: India, 2001, 51.

[16] Kam, T. S.; Choo, Y. M. A new structural class of monoterpenoid indole alkaloids from Kopsia. Helv. Chim. Acta, 2004, 87, 991-998. Gunatilaka, A. A. L.; Fernando, H.; C.; Atta-ur-Rahman; Qureshi, M.; M.; Balasubramaniam, S. Studies on Medicinal and Related Plants of Sri Lanka. Part 19, Neisosposinine: A New Oxindole Alkaloid from Neisosperma oppositifiolia (Apocynaceae). Heterocycles, 1988, 28, 999-1005. 
[18] Plat, M. M.; J. le. Janot, M. M.; Wilson, J. M. Budzikiewicz, H. Durham, L. J. Nagakawa, Y. Djerassi, C. Mass spectrometry in structural and stereochemical problems tabersonine (alkaloids of Amsonia Tabernaemontana Walt). Tetrahedron Lett., 1962, 3(7), 271-276.

[19] Yamauchi, T.; Abe, F.; Padolina, W. G.; Dayrit, F. M. Alkaloids from leaves and bark of Alstonia scholaris in the Philippines. Phytochemistry, 1990, 29(10), 3321-3325.
[20] Kan, C.; Deverre, J. R.; Sevenet, T.; Quirion, J. C.; Husson, H. P. Indole alkaloids from Kopsia deverrei. Nat. Prod. Lett., 1995, 7, 275-281.

[21] Layne, T. H.; McLean, S.; Reynolds, W. F. Tinto, W. F. Excelsinidine, A Quaternary Alkaloid from Aspidosperma excelsum. Nat. Prod. Commun., 2007, 2(6), 649-652.

Received: May 29, 2013

Revised: August 20,2013

Accepted: September 11,2013

(C) Ahmad et al.; Licensee Bentham Open.

This is an open access article licensed under the terms of the Creative Commons Attribution Non-Commercial License (http://creativecommons.org/licenses/by$\mathrm{nc} / 3.0 /$ ), which permits unrestricted, non-commercial use, distribution and reproduction in any medium, provided the work is properly cited. 